B.K. Ostafiychuk ${ }^{1}$, Z.M. Lyubun ${ }^{2}$, R.P. Lisovskiy ${ }^{3}$, M.I. Moiseienko ${ }^{3}$, B.I. Rachiy ${ }^{1}$, N.Ya. Ivanichok ${ }^{1}$, Kh.V. Bandura ${ }^{3}$

\title{
Modeling of Forming a Nanoporous Structure of Carbon Materials forElectrodes of Electrochemical Capacitors
}

\author{
${ }^{l}$ Vasyl Stefanyk Precarpathian National University, Ivano-Frankivsk, Ukraine, bogdan_rachiy@ukr.net \\ ${ }^{2}$ Ivan Franko National University of Lviv, Lviv, Ukraine, zinovijlyubun@gmail.com \\ ${ }^{3}$ Ivano-Frankivsk National Medical University, Ivano-Frankivsk, Ukraine, rlisovsky@ifnmu.edu.ua
}

\begin{abstract}
The paper presents the results of predicting the physical properties of nanoporous carbon materials during synthesis with their subsequent use as an electrode material for electric double layer capacitors. It has been established a multilayer neural network can be used to predict the sorption properties of nanoporous carbon materials. A multilayer neural network confirms the experimental dependences of the characteristics of nanoporous carbon materials porous structure on the technological conditions of its obtaining.

Keywords: nanoporous carbon material, thermochemical activation, multilayer neural network, predicting the properties of materials, specific surface area, electrochemical capacitor.
\end{abstract}

Received 09 June 2020; Accepted 15 June 2020.

\section{Introduction}

Expanding the area of activated carbon use and increasing requirements for operational parameters of devices based on it requires the development of fundamentally new methods of obtaining carbon material (CM) and the use as raw materials (RM) of materials that, not only available and affordable, but have defining properties in the formation of the porous structure of the synthesized material.

Depending on the area of CM application providing the necessary sorption and energy-intensive properties in it is possible both in its synthesis and by chemical and thermal treatment of the obtained material. It should be noted that the sorption properties of CM strongly depend on the structure and composition of the RM, so choosing of RM in many cases may be decisive depending on the areas of application of CM $[1,2]$. The optimization of technological processes of heat treatment in combination with chemical activation of RM and obtaining nanoporous $\mathrm{CM}(\mathrm{NCM})$ with predetermined properties is an urgent scientific and practical task.

The most common methods of NCM obtaining, as it is mentioned above, are the physical or chemical activation of carbon-containing RM. Chemical activation of CM is usually possible at temperatures $(673-1073 \mathrm{~K})$ and it is provided by the use of dehydrating agents, such as phosphoric acid, potassium and sodium hydroxide, zinc chloride [3, 4]. It should be noted that the optimization of methods for obtaining and activating NCM requires a large number of experimental studies i.e. a lot of material and time $[5,6]$. Therefore, to create a mathematical model of the dependence of the porous structure characteristics of NCM on the technological conditions of its obtaining is an urgent task. It will make possible to predict properties of NCM depending on various technological parameters, and this, in turn, will lead to the possibility of determining the direction of the search for optimal characteristics of materials.

\section{Materials and methods}

A material with a fibrous structure of plant origin (hemp shives) was used as a RM. NCM was obtained by thermochemical activation of RM with orthophosphoric acid in the temperature range of $723-823 \mathrm{~K}$ with a step of $50 \mathrm{~K}$ and varying the amount of acid and precursor [6, 
7]. The samples were labeled according to the ratio of the mass of acid to the mass of the RM and the activation temperature. For example, BK-125-550 is the material obtained by mixing acid and $\mathrm{RM}$ in a ratio of $\mathrm{Y}=1: 1.25$ and activated at a temperature of $823 \mathrm{~K}\left(550^{\circ} \mathrm{C}\right)$.

The porous structure of the carbon material was evaluated based on nitrogen sorption isotherms using a device Quantachrome Autosorb Nova 2200e. Specific surface area and pore size distribution were calculated using the Brunauer-Emmet-Teller (BET) method and density functional theory (DFT), respectively.

Studies of the electrochemical properties of NCM were carried out on the AUTOLAB PGSTAT12 of "ECO CHEMIE" company (Netherlands), complete with GPES program.

To predict materials` physical properties a mathematical model of a physical object is necessary to be developed. The model should be characterized by a set of input values given by the input parameters vector $\vec{x}$ determining the properties of the material i. e. the output parameters vector $\vec{y}$. The mathematical model is an equation system (algebraic, integral and differential) which enables calculating the output parameters vector $\vec{y}$ according to a given input parameters vector $\vec{x}$.

The complexity of physical processes occurring in the investigated material brings about significant difficulties in implementing the mathematical model using mathematical dependencies in the form of equations system. However, the use of neural networks makes it possible to avoid this problem (to avoid but not completely solve). Let there is the neural network structure and it is considered that after it was trained, it is the mathematical model of a physical object and it can be used for prediction.

To train the neural network the training pairs are required (as many as possible) $\left(\vec{x}^{i}, \vec{y}^{i}\right)$, where $\vec{y}^{i}$ is the output vector value $\vec{y}$ for the given input $\vec{x}^{i}$.

The created neural network, practically, is an approximator, which makes it possible to determine the properties of the physical system at arbitrary values $\vec{x}^{i}$.

Neural networks are considered as versatile approximators [8, 9]. Kolmogorov's theory defines the ability of neural networks for approximation of multidimensional functions [10]. Using Kolmogorov's theorem, one can choose the neural network with a minimally complex structure to approximate an arbitrary function of many variables. Therefore, Kolmogorov's theorem plays an important role in the neural network theory. It provides the mathematical reasoning of the possibility of implementing an arbitrary multidimensional function by representing this function using simpler functions.

The most all-purpose and most commonly used neural structure that is used to solve the approximation problem is a multilayer perceptron, whose structure is shown in Fig. 1.

According to Kolmogorov's theorem, one hidden layer with the number of neurons $2 N+1$, is sufficient to approximate an arbitrary function, where $N$ is the dimension of the function [10]. The calculation of the number of layers according to Kolmogorov's theorem is theoretical. For practical problems, the number of hidden layers ranges from $N$ to $3 N$ and the number of hidden layers ranges up to two [8].

The use of neural networks to predict the measurement results of physical experiments has its own characteristics and requires pre-processing of input data. Pre-processing involves, if it is necessary, the removal of noise components and data normalization i.e. reduction to specified limits, usually within [0..1]. Data normalization speeds up the training process of neural networks and it is necessary when using the activation function, which have compressive properties. For example, for the sigmoidal activation function, the value at the output of the neuron can change only in the range $[0 \ldots 1]$.

When using the neural network for prediction, one have to take into account that the predicted values at the output of the network can not exceed one.

The following dependence can be used to normalize the input and output vectors of the neural network:

$$
x_{i}^{H}=\frac{\left(x_{i}-x_{\max }\right)(b-a)}{x_{\max }-x_{\min }}+a,
$$

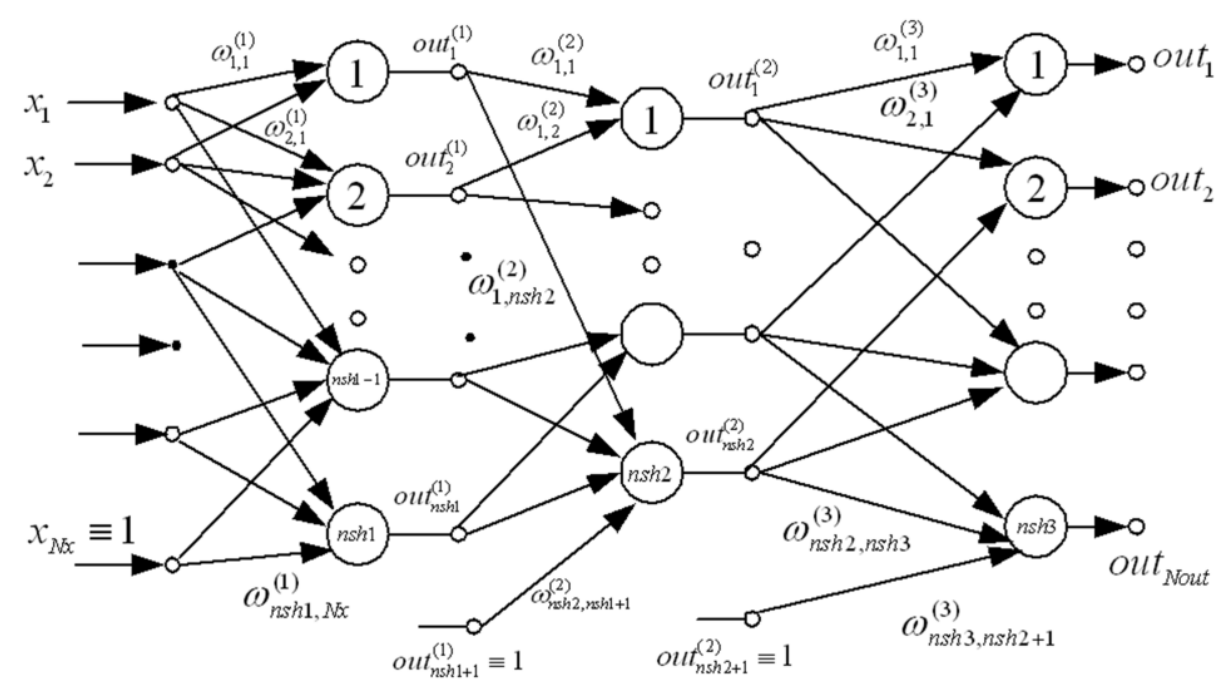

Fig. 1. The structure of multilayer neural network. 


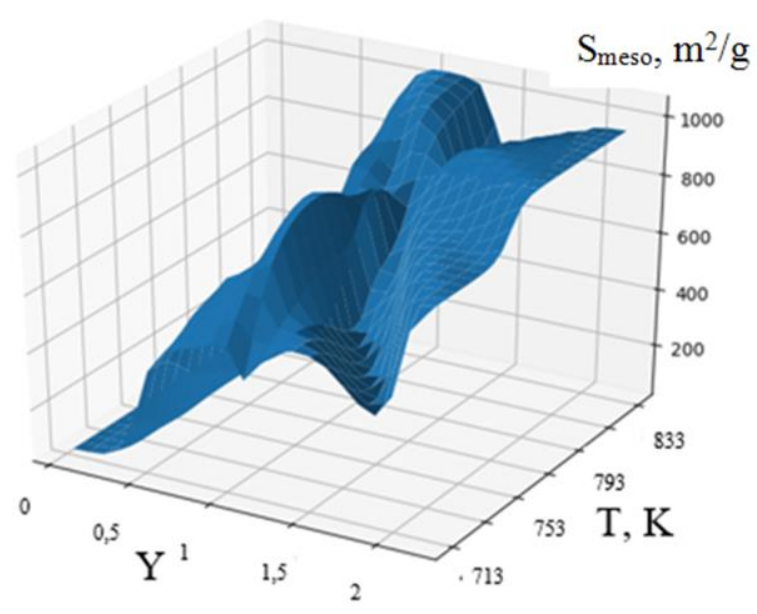

Fig. 2. The dependence of mesopore area on activation agent/RM ratio and activation temperature.

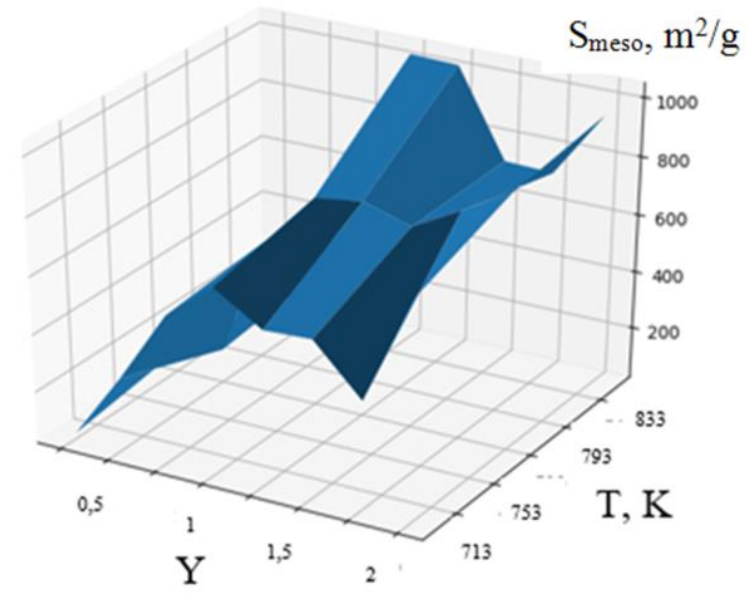

Fig. 3. Predicting dependency of mesopore area on acid/RM ratio and activation temperature within the interval of experimental data.

where $x_{i}$ is non-normalized data, $x_{\max }, x_{\min }$ are maximum and minimum value from input data array, $b$ and $a$ are upper and lower limits of normalized data, respectively.

The inverse operation to return to real physical parameters is performed by the formula:

$$
x_{i}=\frac{\left(x_{i}^{H}-a\right)\left(x_{\max }-x_{\min }\right)}{b-a}+x_{\min } .
$$

\section{Results and discussion}

To train the neural network the characteristics of NCM porous structure were used: total specific surface area $\left(\mathrm{S}_{\mathrm{BET}}\right)$, mesopore area $\left(\mathrm{S}_{\mathrm{meso}}\right)$ and micropore area $\left(\mathrm{S}_{\text {micro }}\right)$ were used. These characteristics are calculated based on adsorption/desorption isotherms [6, 7]. These parameters of NCM, as well as their ratio, are the main factors in the accumulation of electrical energy when using it as an electrode material for electrochemical capacitors (EC).

A three-layer perceptron with a sigmoidal activation function was used to approximate the parameters of the porous structure of the NCM from the technological conditions of production. Trained network was used to predict the dependency of $S_{\text {meso }}$ and $S_{\text {micro }}$ values on acid/RM ratio and temperature of activation process both within the range of input parameters and outside them.

The dependency of $S_{\text {meso }}$ values on acid/RM ratio and temperature of activation based on experimental data [6] is presented in Fig. 2.

Fig. 3 shows the approximation results that can be used to predict the value of $S_{\text {meso }}$ within the interval of experimental studies.

Fig. 4 demonstrates how the obtained neural network model is used in the extended range of output parameters outside the experiments.

The neural network model allows to determine the optimal output parameters. For example, the maximum value of $S_{m e s o}=1035 \mathrm{~m}^{2} / \mathrm{g}$ can be obtained at acid/RM ratio of 1.22 and at the temperature of activation process of $800 \mathrm{~K}$ [11].

It should be noted that when using NCM as an electrode material in electrochemical capacitors, ensuring the maximum values of the specific area of mesopores and their homogeneity is not sufficient to achieve high energy parameters $[5,12]$. Since the value of the specific surface area of the electrode material does not always correlate with the value of the accumulated capacitance, almost only $30-50 \%$ of this surface is electrochemically available, which corresponds to a specific capacity value of $\sim 150 \mathrm{~F} / \mathrm{g}$. A sufficient condition, according to the authors [7, 12], is the creation of certain ratios of size, the so-called "working (active)" and "transport" pores and the type of electrolyte.

In order to establish a correlation between the specific surface area of pores of different diameters and the capacitance of the NCM/electrolyte system, the dependence of the specific capacitance of the NCM on the working current was determined. Studies of the energy parameters of the obtained NCM were performed using a two-electrode cell. Button-type electrodes were prepared by pressing a mixture of the following composition into a nickel grid: NCM (75\% by weight), a

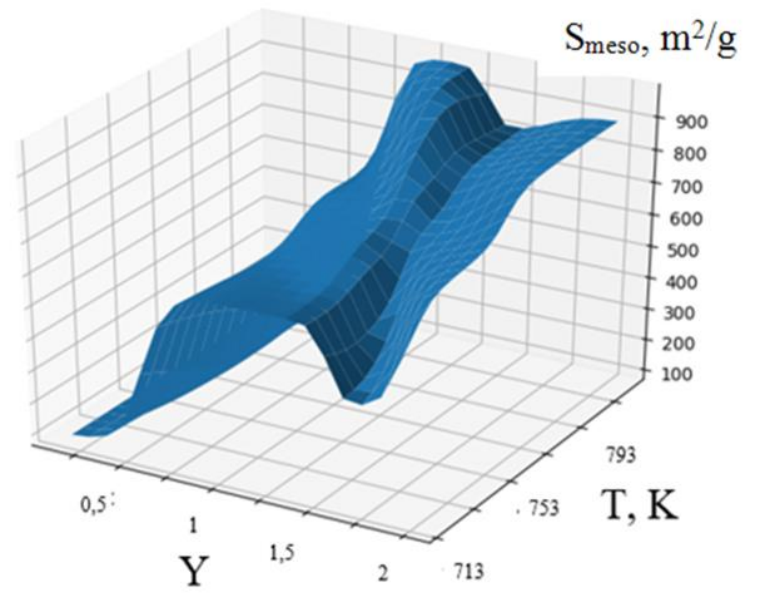

Fig. 4. Predicting dependence of mesopore area on acid/RM ratio and activation temperature outside the interval of experimental data. 


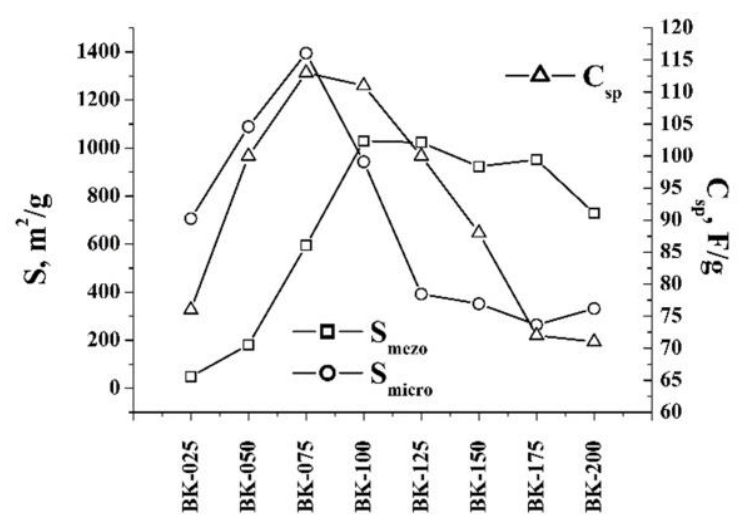

Fig. 5. Specific sorption and capacitance characteristics of NCM obtained at activation temperature of $823 \mathrm{~K}$.

conductive additive (20\% by weight) and a binder $(5 \%$ by weight). The formed electrodes were separated by a separator and placed in an EC model, where it was filled with electrolyte (30\% aqueous $\mathrm{KOH}$ solution) and sealed.

The specific capacitance values of NCM are calculated using the chronoamperometric method at a discharge current of $1 \mathrm{~mA}$ and are presented in Fig. 5. As can be seen from the Fig. 5, the maximum value of the specific capacitance $(113 \mathrm{~F} / \mathrm{g})$ is obtained for EC models formed on the basis of BK-075-550 used $30 \%$ aqueous solution of $\mathrm{KOH}$ as an electrolyte.

\section{Conclusion}

Thus, based on carried experiments, it can be affirmed that a multilayer neural network can be used to predict the physical properties of NCM.

The obtained values of specific capacitance indicate the importance of obtaining certain ratios between the values of the specific surface area of micropores $\left(S_{\text {micro }}\right)$ and mesopores $\left(S_{\text {meso }}\right)$ of NCM, and the use of prediction using neural networks makes it possible to minimize long-lasting and energy consuming experimental studies.

Ostafiychuk B.K. - Professor, Doctor of Physical and Mathematical Sciences, Doctor of Sciences, Head of the Department of Material Science and New Technology; Lyubun Z.M. - Candidate of Technical Sciences, Associate Professor at the Radiophysics and Computer Technologies Department;

Lisovskiy R.P. - Doctor of Physical and Mathematical Sciences, Associate Professor at the Department of Medical Informatics, Medical and Biological Physics;

Moiseienko M.I. - Doctor of Biological Sciences, Full Professor, Head of the Department of Medical Informatics, Medical and Biological Physics;

Rachiy B.I. - Doctor of Physical and Mathematical Sciences, Professor at the Department of Material Science and New Technology;

Ivanichok N.Ya. - Candidate of Physical and Mathematical Sciences, Leading Specialist of Joint Educational and Scientific Laboratory;

Bandura K.V. - Candidate of Physical and Mathematical Sciences, assistant at the Department of Medical Informatics, Medical and Biological Physics.

[1] B.E. Conway, Electrochemical Supercapacitors: Scientific Fundamentals and Technological Applications (N.Y. Kluwer Academic Plenum Publishers, 1999).

[2] T.Ya. Boychuk, I.M. Budzulyak, N.Ya. Ivanichok, R.P. Lisovskiy, B.I. Rachiy, Journal of Nano- and Electronic Physics 7(1), 01019-1 (2015).

[3] B. Viswanathan, P. IndraNeel, T. Varadarajan, Methods of Activation and Specific Applications of Carbon Materials (Chennai: National Centre for Catalysis Research Indian Institute of Technology Madras, 2009).

[4] M. Inagaki, H. Konno, O. Tanaike, Journal of Power Sources, 195(24) 7880 (2010) (DOI: 10.1016/j.jpowsour.2010.06.036).

[5] B.K. Ostafiychuk, I.M. Budzulyak, B.I. Rachiy et al., Journal of Nano- and Electronic Physics 9(5), 05001 (2017) (DOI: 10.21272/jnep.9(5).05001).

[6] B.K. Ostafiychuk, R.P. Lisovskiy, A.H.Z. Al-Saedi et al. Journal of Nano- and Electronic Physics 11(3) 03036 (2019) (DOI: 10.21272/jnep.11(3).03036).

[7] N. Ivanichok, I. Budzuliak, M. Moiseienko, R. Lisovskiy, B. Rachii, A. Gamarnyk, L. Turovska, S. Lisovska, Physics and Chemistry of Solid State 21(1), 35 (2020) (DOI: 10.15330/pcss.21.1.35-42).

[8] S. Osovsky. Neural networks for information processing (Moskow, 2002).

[9] K. Funahashi, Neural Networks. 2(3) 183 (1989) (DOI: 10.1016/0893-6080(89)90003-8).

[10] A.N. Kolmogorov, Reports of AN USSR 114(5) 953 (1957).

[11] R. Lisovskyi, I. Poplavskyi, B. Rachii, Z. Lyubun, Modeling of carbon materials porous structure formation. Electronics and information technologies: X-th International scientific and practical conference Elite-2018. Lviv, Ukraine, B70 (2018).

[12] M. Endo, Y.J. Kim, T. Takeda et al. Journal of The Electrochemical Society 148(10) A1135 (2001). 
Б.К. Остафійчук ${ }^{1}$, 3.М. Любун ${ }^{2}$, Р.П. Лісовський ${ }^{3}$, М.І. Мойсеєнко ${ }^{3}$, Б.І. Рачій ${ }^{1}$, Н.Я. Іванічок ${ }^{1}$, Х.В. Бандура ${ }^{3}$

\title{
Моделювання процесу формування нанопористої структури вуглецевих матеріалів для електродів електрохімічних конденсаторів
}

\author{
${ }^{I}$ Прикарпатський національний університет імені Василя Стефаника, Івано-Франківськ, Украйна, \\ bogdan_rachiy@ukr.net \\ ${ }^{2}$ Львівський наиіональний університет імені Івана Франка, Львів, Україна, zinovijlyиbип@ gmail.com
}

${ }^{3}$ Івано-Франківський національний медичний університет, Івано-Франківськ, Україна, rlisovsky@ifnmи.еdи.иа

У роботі представлені результати прогнозування фізичних властивостей нанопористих вуглецевих матеріалів в процесі отримання 3 подальшим застосуванням їх як електродного матеріалу для електрохімічних конденсаторів, заряд яких накопичується в подвійному електричному шарі. Встановлено, що багатошарову нейронну мережу можна використовувати для прогнозування сорбційних властивостей нанопористих вуглецевих матеріалів, яка підтверджує експериментальні залежності характеристик їх пористої структури від технологічних умов отримання.

Ключові слова: нанопористий вуглецевий матеріал, термохімічна активація, багатошарові нейромережі, прогнозування властивостей матеріалів, питома площа поверхні, електрохімічний конденсатор. 